\title{
Floriculture Business Triumphs All Other Farm Businesses: A Case Study
}

\author{
Z. A Bhat ${ }^{1}$, M.H. Khan ${ }^{2}$, M. A. Wani ${ }^{1}$, B. Hamid ${ }^{1}$, Shayista Nabi ${ }^{1}$ \\ ${ }^{1}$ Division of Floriculture and Landscape Architecture, SKUAST- Kashmir \\ ${ }^{2}$ Advanced Research Station for Saffron and Seed Spices, SKUAST-Kashmir \\ Corresponding Author: M.H. Khan
}

DOI: https://doi.org/10.52403/ijrr.20220312

\begin{abstract}
Kashmir agro-climatic conditions are known to be the god's choice for growing flowers. The conditions are so blended and suited to the crops especially bulbous geophytes that most of the farmers have recorded or obtained unprecedented quality and quantity. We documented one such study from flower grower (Mr. Arshid Ahmad Mir) residing in the remote village of Shar-Shalli, district Pulwama of Kashmir valley. This farmer was known to us as a keen, interesting, and hardworking. The important attributes associated with him is that he was always attending the training programmes from our university, state floriculture department etc. His curiosity for expanding the business with proper guidance, scientific approaches of farming and tackling the on and off farm challenges with the technical know-how from the concerned persons of farm university has beard him the fruits of success. He has successfully triumphed the all odds of lilium cultivation, thus has become the epitome of flower grower for other flower growers of valley.
\end{abstract}

Keywords: Cut flower; bulb production; empowerment; livelihood

\section{INTRODUCTION}

Floriculture is the branch of horticulture concerning cultivation of lowering and ornamental plants for gardens and floristry. It includes cut flowers, cut greens, bedding plant, houseplants, flowering garden and pot plants etc. It is a fast growing industry. Urbanization and rising living standards of the people has led to steady increase in demand of flowers and flower, products making floriculture as one of the most important commercial trades in Agriculture. Floriculture has a vast scope and potential in the valley, which is evident from the fact that during the year 1996, an area of $80 \mathrm{Ha}$ was under flower cultivation in $\mathrm{J} \& \mathrm{~K}$, which has currently expanded to the level of $350 \mathrm{Ha}$, an annual turnover of about 1350 lakhs. Further, more than 1500 Youth are directly engaged under commercial floriculture sector in Kashmir division. Moreover, an area of about 9.297 hectares has been covered under protected cultivation, in private sector by raising Tubular Structure Poly Houses; High Tech Poly Houses, Shade Net Houses etc. (Wani et al., 2016). The area under the sector is increasing day by day and more and more people are turning towards floriculture. Consequently, keeping in view the prospectus and neck breaking pace of ever growing floriculture in Kashmir valley we come up with an idea to document a success story from a progressive farmer namely $\mathrm{Mr}$. Arshid Ahmad Mir, the details obtained are discussed below

\section{Success story of Farmer}

As we have already setup some selfhelp groups associated with NMHS project, among one self-help group we selected one keen and interesting farmer namely $\mathrm{Mr}$. Arshid Ahmad Mir. After that we had set up a demonstration trail under protected 
cultivation on lilium. The planting material was provided to him and the demonstration was laid out in single polyhouse of $60 \times 20$ feet dimension. The principal investigator along with the project staff were having regular field visits and imparted the on farm training programme among the family. Various approved scientific agro-techniques related to the lilium cultivation were disseminated among the family and were inculcated with the first hands on training on cultivation, bulb production and postharvest handling. We got unprecedented results related to the quality and quantity of cut flower and bulb production. He was having total of 6 polyhouses (Table 1) among which one polyhouse was installed from our side funded by NMHS project entitled "Livelihood improvement and empowerment of rural poor through quality bulb production and cut flowers under temperate conditions of Kashmir valley". This family is so successful (Fig 1,2 and 3) in a way that other farmers used to visit to his farm and took the suggestions and advise from him. The farmer has got so much confidence that he has abandoned the other farm business like maize, paddy etc. and he expanded the programme to other flower crops like gladiolus, gerberas, rose etc. it is worth to mention here that we also provided him with the gladiolus plating material for open filed cultivation. Excluding the revenue from polyhouse he got an amount of 15,000 per kanal for open gladiolus cultivation. Finally, he is of view that if a man is keen, interesting and honest he can make gold mountains (revenue) out of pebbles (flowers).

Table 1: Input cost and net income of grower in floriculture business.

\begin{tabular}{|c|l|c|}
\hline $\begin{array}{c}\text { S. } \\
\text { No. }\end{array}$ & \multicolumn{1}{|c|}{ Inputs/Cost incurred } & Cost \\
\hline 1. & Total number of bulbs & 30,000 \\
\hline 2. & Cost per bulb & 21 \\
\hline 3. & Input cost of bulbs & 630,000 \\
\hline 4. & Minimum cost of cut lilium spikes per bundle & 350 \\
\hline 5. & Number of bulbs harvested & 2400 \\
\hline 6. & Gross income per polyhouse & 40000 \\
\hline & Net income from 6 polyhouses & $\mathbf{2 4 0 , 0 0 0}$ \\
\hline
\end{tabular}

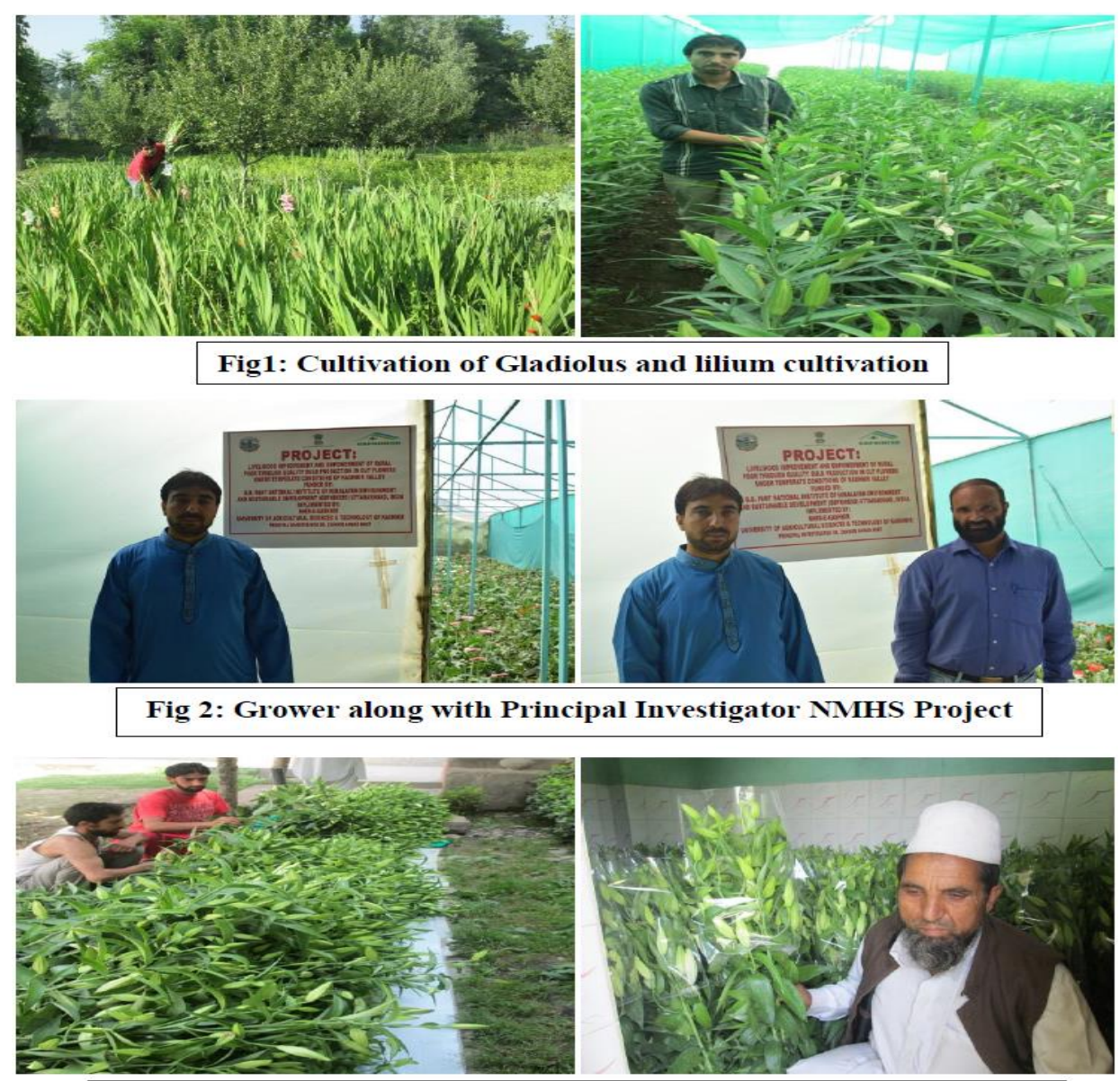

Fig 3: Harvesting in full swing, the mostly uses his own family 


\section{CONCLUSION AND RECOMMENDATIONS}

From the current case study, we could draw an inference that floriculture business could a very lucrative business among all the farm businesses. In Kashmir valley the climate conditions, manpower and other inputs are not the limiting factors. What needs is that one associated with the business should have patience, honesty and be socially interactive. The keen for business along with the interest for developing entrepreneurial qualities through trainings, exposure visits and consultation of floriculture experts can have a tangible impact on grower's income generation. In recommendations we are of view that there should be vigorous on form demonstrations (OFT's and FLD's), district to district trainings and advertisement of various approved optimised farm practise through various media channels and, keeping in view the fragility of environment.

\section{Acknowledgements}

Authors thanks to "National Mission on Himalayan Studies (NMHS), G. B Pant National Institute of Himalayan
Environment and Sustainable Development, Kosi- Katarmal, Almora, Uttarakhand, India and Ministry of Forestry and Climate Change, New Delhi, India" for providing the financial support, we are also thankful to Division of FLA, SKUAST-K, concerned farmer, and programmer coordinator $\mathrm{KVK}$ Pulwama.

\section{Conflict of Interest: None}

\section{Source of Funding: None}

\section{REFERENCE}

1. Wani MA, Nazki IT, Sheikh M, Neelofar, Din A, Hassan S and Peer QJA (2016) Diversification through floriculture in Kashmir Valley. In: Bhat A, Singh SP (eds) Agricultural Marketing: Perspectives and Potentials. New India Publishing Agency (nipa), Jammu, pp 209-233

How to cite this article: Z.A Bhat, M.H. Khan, M. A. Wani et.al. Floriculture business triumphs all other farm businesses: a case study. International Journal of Research and Review. 2022; 9(3): 96-98. DOI: https://doi.org/ 10.52403/ijrr.20220312 